\title{
Od retoryki ekfrazy do antropologii kina. Współczesna poezja filmowa a „opowiadanie filmów”
}

\section{Rafał Koschany}

ORCID: 0000-0002-9343-9885

\section{Uwagi wstępne}

Obecność kina i filmu w polskiej poezji właściwie od samego początku XX wieku do dziś jest intensywna, chociaż należy odnotować, że fascynacja nową sztuką poetów w dwudziestoleciu międzywojennym była bardziej zachłanna i dała chyba ciekawsze rezultaty zarówno formalne, w zakresie rozwoju języka poetyckiego oraz poszerzania jego granic, jak i w kontekście genologicznym. Wykształciły się na przykład wówczas specyficzne gatunki poetyckie, w których film i filmowość dominowały na specjalnych, ściśle określonych zasadach - takie jak, publicystyczna w konwencji, poetycka recenzja z filmu, film raconté (czyli film opowiedziany) ${ }^{1}$, poemat

\footnotetext{
${ }^{1}$ Por. Grażyna Szymczyk-Kluszczyńska, „Opowiadam? Opisuję? (Poeci-surrealiści wobec kina)”, w Małe formy narracyjne, red. Eugenia Łoch (Lublin: Wydawnictwo UMCS, 1991).
} 
kinematograficzny ${ }^{2}$ czy wreszcie powieść filmowa ${ }^{3}$. Współczesne nawiązania do kina i filmu (filmów) z kolei są liczne, ale rozproszone. Generalnie rzecz ujmując, zachodzi tu swego rodzaju odpowiedniość: film i kino należą do codziennej kultury, a co za tym idzie - do codziennego języka oraz języka poetyckiego.

Tytułowa „współczesność” nie jest okresem wyznaczonym precyzyjnie, ale pozwala postawić najważniejszą cezurę w historycznym rozwoju relacji, o której mowa - między poezją pierwszych dekad XX wieku właśnie a poezją już powojenną, w tym najnowszą. Oprócz wszystkich istotnych elementów, które te dwa okresy różnicują, dochodzi jeszcze i ten związany z problematyką ekfrazy: wcześniej obecnej, jeśli już, na zasadzie formalnego eksperymentu, później - z coraz pełniejszą świadomością retorycznych obciążeń gatunku

We współczesnej poezji filmowej mają swoje reprezentacje rozmaite „tematy filmowe”, podejmowano w niej próby „naśladowania” filmu (nawet jeśli były to gesty nieintencjonalne, świadczące o „filmowym” sposobie widzenia i obrazowania), wreszcie z różnym skutkiem film i kino stanowiły - jako powszechnie znane, wręcz zinterioryzowane „światy” i systemy skojarzeń - podstawę budowania metafor, porównań, analogii. „U nas teraz wszystko tak filmowe” - jak pisze w wierszu Do S. Wyspiańskiego Marta Berowska ${ }^{5}$. Niezależnie od rozmaitych prób systematyzacji niezwykle obfitego materiału polskiej współczesnej poezji filmowej wyróżnić można grupę wierszy, w których pojawiają się nawiązania do konkretnych filmów. Nie stanowią one li tylko ozdobników, nie występują na zasadzie przywołań - jednych z wielu - elementów kultury popularnej czy intertekstualnych aluzji, nie są popisem erudycji albo pustym znakiem „ducha czasów” (chociaż takich przypadków też jest całkiem sporo), ale wyróżniają się jako próby pogłębionego (poetyckiego) namysłu nad filmowymi obrazami. Szukając inspiracji teoretycznych w refleksji poświęconej obecności malarstwa i muzyki w literaturze, a zwłaszcza w poezji, skłaniam się do postawienia tezy, że wyodrębnienie niektórych cech charakterystycznych wybranych do analizy kilkunastu wierszy pozwala rozpoznać w nich przykłady ekfraz.

\section{„Opowiadanie filmów” - konteksty kulturowe i teoretyczne}

W próbach odpowiedzi na pytanie, czy w ogóle możliwa jest poetycka ekfraza dzieła filmowego, warto odwołać się do skojarzenia z tradycją „opowiadania filmów”, która - jako czynność,

\footnotetext{
${ }^{2}$ Por. Grażyna Szymczyk-Kluszczyńska i Ryszard W. Kluszczyński, „Poemat kinematograficzny. Analiza pewnego typu związków między literaturą a kinem”. Przegląd Humanistyczny nr 11 (1982).

${ }^{3}$ Por. Alina Madej, „Między filmem a literaturą. Szkic o powieści filmowej”, w Film polski wobec innych sztuk, red. Alicja Helman i Alina Madej (Katowice: Uniwersytet Śląski, 1979); Janusz Kucharczyk, „Pierwiastki filmowe w twórczości literackiej Tadeusza Peipera i Jalu Kurka”. Kwartalnik Filmowy nr 1 (1965).

${ }^{4}$ Dlatego też w niniejszej propozycji, a także z konieczności ograniczenia pola refleksji, nie biorę pod uwagę twórczości dwudziestolecia międzywojennego - mimo wielu nawiązań do konkretnych filmów w niej zapisanych. Poezja filmowa tego okresu jest również trochę dokładniej już opracowana. Por. m.in.: Ewa i Marek Pytaszowie, „Poetycka podróż w świat kinematografu, czyli kino w poezji polskiej lat 1914-1925”, w Szkice z teorii filmu, red. Alicja Helman i Tadeusz Miczka (Katowice: Uniwersytet Śląski, 1978), 18-32; Wojciech Otto, Literatura i film w kulturze polskiej dwudziestolecia międzywojennego (Poznań: Wydawnictwo PTPN, 2007).

${ }^{5}$ Marta Berowska, „Do S. Wyspiańskiego”, Poezja nr 7-8 (1985): 93.
} 
wydawałoby się, właściwie codzienna i powszechna - nieczęsto bywa uwzględniana w ramach rekonstruowania historii kina, obejmującej również wiele praktyk okołofilmowych, a nie tylko same dzieła i ich twórców. Pomijając jednak warstwę zagadnienia czysto anegdotyczną, w której przypadku opowiadanie filmów na „codzienne” potrzeby zainteresowanych ${ }^{6}$ stawało się nawet przedmiotem dowcipów ${ }^{7}$, można spojrzeć na to zagadnienie w sposób stricte historyczny i/lub kulturowy, a także - co interesuje mnie szczególnie - teoretyczny. Ze względu na różnorodność kontekstów, przygotowujących grunt pod refleksję nad „właściwą” ekfrazą filmu, przywołam spośród nich jedynie kilka szczególnie charakterystycznych, we wszystkich przypadkach akcentując poziom „przekładu”, szukania czy budowania swoistego ersatzu: werbalnego „tekstu” względem (ruchomego) obrazu filmowego.

Bodaj najstarsze z zapowiedzianych skojarzeń wiąże się z postacią (i profesjonalnym zawodem) benshi - zewnętrznego względem samego filmu narratora okresu kina niemego w Japonii. Benshi zgromadzonej publiczności nie tylko czytał napisy, ale także „podawał” kwestie postaci (stawał się zatem swego rodzaju aktorem we wspólnym seansie) oraz „interpretował” to, co sugerował obraz, niejednokrotnie celowo przeinaczając sens obcych odbiorcom treści. Jak piszą badacze zagadnienia: „Benshi przekształcili wizualny język kina w język werbalny, toteż wyjaśnienie znaczenia obrazu filmowego było całkowicie uzależnione od ich spojrzenia" ${ }^{\text {. }}$ $Z$ jednej strony mówi się, że kino japońskie powstawało i rozwijało się w odmienny sposób od europejskiego czy amerykańskiego i właśnie dlatego instytucja benshi była w nim tak ważna (obdarzeni szczególną charyzmą „opowiadacze” otoczeni byli większym kultem niż aktorzy), z drugiej - że to właśnie ogromna rola benshi przyczyniła się w dużym stopniu do innej drogi, którą przez dłuższy czas podążała kinematografia japońska, zwłaszcza w zakresie sposobów budowania narracji i wprowadzania dźwięku do filmu w latach trzydziestych XX wieku ${ }^{9}$. Co ciekawe, instytucja benshi przetrwała do dziś, o czym jeszcze niedawno mogła się przekonań nawet polska publiczność ${ }^{10}$ (przetrwała jako kontynuacja zacnej sztuki opowiadania, ale także na fali powrotu do unikalnych i poszukiwanych w dobie globalizacji kulturowej praktyk, w dobie powszechnej dostępności filmów i - co najważniejsze - ich niezmiennego przebiegu podczas każdego seansu).

\footnotetext{
${ }^{6}$ Współcześnie - w sposób nieco paradoksalny - praktyki te znajdują swoistą kontynuację w komputerowych algorytmach czy dostępnych online programach, które „wysłuchują” naszej opowieści (sprowadzanej najczęściej do słów kluczowych), by (p)odpowiedzieć, o jaki film - którego pamiętamy „treść”, ale nie pamiętamy tytułu - może chodzić. Podobną „samopomocową” funkcję pełnią założone specjalnie w tym celu grupy na przykład na Facebooku.

${ }^{7}$ Mowa o cyklu radiowych skeczy z lat siedemdziesiątych XX wieku, pod tytułem Para-męt pikczers czyli kulisy srebrnego ekranu, według scenariuszy Andrzeja Zaorskiego. Jako Jędrek dialogował on z Mańkiem (w tej roli Marian Kociniak) na temat ostatnio obejrzanego filmu, a konwencjonalnie każdy z programów zaczynał się formułą Fajny film wczoraj widziałem...

${ }^{8}$ Hiroshi Komatsu, Charles Musser, „Benshi Search”, cyt. za: Krzysztof Loska, „Benshi jako współautor filmu”. Kwartalnik Filmowy nr 59 (2007): 59.

${ }^{9}$ Por. Loska; Jeffrey Dym, A Brief History of Benshi (Silent Film Narrators), https://aboutjapan.japansociety.org/ content.cfm/a brief history of benshi; Dawid Głownia, Poczqtki kina w Japonii na tle przemian społecznopolitycznych kraju (Wrocław: Atut, 2020). W 1994 roku powstał japońsko-amerykański film Picture Bride (reż. Kayo Hatta), opowiadający historię z początku XX wieku zaaranżowanego na podstawie zdjęć małżeństwa; w jednej ze scen na wsi, gdzie ostatecznie trafia młoda mężatka, odbywa się pokaz objazdowego kina. Filmowe sceny walk samurajów objaśnia zgromadzonej publiczności właśnie benshi. Co ciekawe, w tej roli gościnnie wystąpił ponadsiedemdziesięcioletni wówczas Toshirô Mifune, słynny japoński aktor, znany przede wszystkim z wcześniejszych ról (także samurajów) w filmach m.in. Akiry Kurosawy.

${ }^{10}$ Mowa o wydarzeniu w warszawskim kinie Elektronik (3-4.03.2017), podczas którego zorganizowano pokaz trzech japońskich filmów niemych z towarzyszeniem Ichirō Kataoka, mistrza sztuki opowiadania, o której mowa (wcześniej - w 2015 roku - był on też gościem 12. Święta Niemego Kina).
} 
Co prawda „instytucja” benshi pozostaje charakterystyczna i wyjątkowa dla kina japońskiego, pojawiła się tam i ukształtowała głównie z powodów odmiennych tradycji estetycznych, zwłaszcza teatralnych. Nie ulega jednak wątpliwości, że podobni „opowiadacze” potrzebni byli także gdzie indziej, szczególnie w okresie rozwoju kina niemego, a przyczyną zaistnienia tej funkcji w kinoteatrach całego świata najczęściej był powszechny analfabetyzm, uniemożliwiający czytanie plansz z "didaskaliami” i dialogami postaci, jak również dość powszechne wówczas nieprzygotowanie szerokiej publiczności do odbioru dzieła filmowego - jako sztuki operującej specyficznymi środkami narracji, a także opowiadającej o świecie czasem zupełnie owej publiczności nieznanym. Można się o tym przekonać podczas lektury łódzkiej opowieści Jisroela (Izraela) Rabona, której akcja rozgrywa się w latach dwudziestych XX wieku. Bohater powieści Ulica zostaje zatrudniony w kinie „Wenus” i w ten sposób zdaje relację ze swego pierwszego wystąpienia: „Mówiłem głośno z ogniem i pasją. W sali zapadła cisza. Publiczność słuchała z zapartym tchem moich słów. [...] Gdy skończył się pierwszy akt i zapalono światło, publiczność zaczęła bić brawo i wołać «niech żyje mówca!»”"11.

Nieco innym kontekstem dla rozważań nad kwestią intersemiotycznego przekładu dzieła audiowizualnego jest - z jednej strony - wspomniana już powszechna praktyka opowiadania filmów, z drugiej - jej kulturowo uwarunkowana tradycja. Właśnie taką historię przedstawia Hernán Rivera Letelier w swej krótkiej powieści o znaczącym tytule Opowiadaczka filmów. Rzecz dzieje się w latach sześćdziesiątych XX wieku w małej chilijskiej osadzie, gdzie większość mieszkańców żyje z pracy w kopalni saletry. Jedną z niewielu rozrywek jest kino, ale też niewielu na to kino stać. $Z$ powodu biedy oraz niepełnosprawności ojca pewna rodzina (ojciec samotnie wychowuje czterech synów i - najmłodszą - córkę, Maríę Margaritę) wpada na pomysł, by tylko jedno z dzieci oglądało film, a potem zdawało relację pozostałym. Urządzono nawet odpowiedni konkurs - w którym ostatecznie wygrała bezkonkurencyjna María, „najlepsza opowiadaczka filmów w rodzinie” ${ }^{12}$, niezwykle sugestywnie oddająca przebieg ekranowej historii, wraz z drobiazgowym nakreśleniem tła zdarzeń i coraz bardziej profesjonalnym wcielaniem się w poszczególne postacie, ale jednocześnie korzystająca podczas swych występów z nieograniczonej wyobraźni, a nawet plotki czy drobnej sugestii zawartej choćby w fotosie filmowym. „Gdy opowiadałam film - nie szczędząc gestykulacji ani modulacji głosu - przeobrażałam się w każdą z postaci. Tego wieczoru byłam młodym Ben-Hurem, Messalą, czyli czarnym charakterem, i obiema trędowatymi, które uleczył Jezus. Byłam nawet samiuśkim Jezusem"13. Warte podkreślenia jest także, że sama narratorka docenia znaczenie pewnego przygotowania do odgrywania roli rodzinnej opowiadaczki filmów (i nie tylko, z czasem ukształtowała się tu bowiem swego rodzaju instytucja kulturalna, nawet konkurencyjna względem samego kina) - to jest opowiadanie jej filmów na dobranoc przez mamę. W interesującym mnie ujęciu ważny jest oczywiście sam fakt sugestywnie prowadzonej narracji i potrzeby jej słuchania, jednakże w szerszym aspekcie nie należy zapominać, że historia Leteliera jest w pewien sposób reprezentatywna dla pewnych kontekstów rozwoju odbiorczych praktyk „kinowych”, a także podkreśla wagę ustnie przekazywanej opowieści w życiu jednostek i społeczeństw, w tym ich rolę w kształtowaniu i pracy wyobraźni słuchających.

\footnotetext{
${ }^{11}$ Por. Izrael Rabon, Ulica, tłum. Krzysztof Modelski (Wrocław: Wydawnictwo Dolnośląskie, 1991), 117.

${ }^{12}$ Hernán Rivera Letelier, Opowiadaczka filmów, tłum. Natalia Nagler (Warszawa: Muza, 2012), 12.

${ }^{13}$ Letelier, 31.
} 
Z kolei formuła kina opowiadanego (w języku białoruskim izustnoje kino) definiowana jest jako pojęcie oraz zjawisko stosunkowo nowe i mające konkretną historię (to znaczy nie spotykam go w innych relacjach, ale w związku z tym, że ono również ma swoją genealogię z pewnością analogiczne lub podobne przedsięwzięcia rodziły się także gdzie indziej). Mianowicie w latach osiemdziesiątych XX wieku na Białorusi miało miejsce wzmożenie działalności rozmaitych awangard artystycznych, w tym grupy Białoruski Klimat - multidyscyplinarnej formacji, która w ramach swej działalności zainicjowała również praktykowanie „kina opowiadanego". Oczywiście ważny był tutaj szerszy kontekst, w tym raczkujący rynek związany z magnetowidami i kasetami VHS: wypożyczanie filmów, wymienianie się nimi, ad hoc organizowane kina domowe, a także - opowiadanie sobie tych filmów i o tych filmach. Kino opowiadane w wykonaniu twórców Białoruskiego Klimatu to jednak już twórczość w pełni autonomiczna, sytuująca się pomiędzy filmem, literaturą ustną a performansem: opowiadany film jest tu "wymyślony” (to znaczy nie ma swego pierwowzoru), wraz z całą fabułą, a nawet przynależnością gatunkową (również muzyka jest w nim opowiedziana) - w przeciwieństwie do raczej odtwórczego (pomijając kwestię talentu i autorskich zapędów) charakteru występów „opowiadaczki filmów” z książki Leteliera i wielu innych podobnych „opowiadaczy”. Alena Siutsova, autorka pracy magisterskiej poświęconej niszowemu i odosobnionemu fenomenowi kina opowiadanego ${ }^{14}$, w próbie możliwie szerokiej, teoretycznej charakterystyki gatunku przywołuje również pojęcie ekfrazy, oczywiście z zastrzeżeniem, iż de facto brakuje tu tego, co opisywane, oryginału, jednak równie ważne jest - tak w ekfrazie, jak w kinie opowiadanym uzyskanie podobnego efektu po stronie odbiorcy i jego wyobraźni, to jest mentalnego obrazu / ruchomych obrazów. Co prawda równie ciekawe byłoby tu przywołanie tradycji hypotypozy (definiowanej jako opis unaoczniający, tak sugestywny, że zdolny wywołać odpowiedni ekwiwalent w wyobraźni słuchacza bądź czytelnika, niekoniecznie odnoszący się do istniejącego dzieła sztuki), faktem pozostaje, że kino opowiadane to interesujący przykład praktyki, którą można by określić jako próbę uzyskania efektu kina - bez jego bezpośredniego udziału, ale $z$ uwzględnieniem wszystkich zmian, jakich dokonało ono w sposobach widzenia, wyobrażania sobie, wreszcie opowiadania.

Ostatnia wzmianka, która przybliża do intersemiotycznych rozważań na temat ekfrazy, dotyczy kwestii nie nowej, ale współcześnie bardzo aktualnej, coraz intensywniej wprowadzanej w życie i poddawanej teoretycznemu namysłowi. Mowa o audiodeskrypcji, której przywołanie umożliwia konfrontację dwóch rodzajów opisu: filmu oraz dzieła plastycznego (audiodeskrypcja - także w kontekście instytucjonalnym - pojawiła się nieco szybciej we współczesnych praktykach muzealnych, dopiero potem w kinie i telewizji). Warto podkreślić, że tradycję audiodeskrypcji (najczęściej tę związaną z dziełami sztuki plastycznej) niejednokrotnie łączy się z teorią ekfrazy właśnie ${ }^{15}$. W rozumieniu audiodeskrypcji filmowej jako „narzędzia”, jako pewnej funkcjonalności, która ma odegrać określoną rolę w dostarczeniu „filmowego” przekazu osobom niewidomym i niedowidzącym, „tekst docelowy” nie aspiruje do bycia sztuką. Ale jednocześnie coraz częściej badacze zagadnienia podnoszą kwestię jakości takiego „tekstu” - nie ulega bowiem wątpliwości, że odbiór filmu dzięki jego językowemu przekładowi w ogromnym

\footnotetext{
${ }^{14}$ Por. Alena Siutsova, „Kino opowiadane. Historia i teoria” (praca magisterska, Uniwersytet Warszawski, 2014).

${ }^{15}$ Por. Robert Więckowski, „Audiodeskrypcja piękna”. Przekładaniec nr 28 (2014); Beata Jerzakowska, „Ekfraza poetycka w audiodeskrypcji”, Polonistyka nr 5 (2013).
} 
stopniu zależy od - właśnie - rodzaju zaproponowanej narracji. Można powiedzieć, że w tym sensie praktyka audiodeskrypcji skupia w sobie wszystkie doświadczenia i tradycje, o których była mowa powyżej. W interesującym mnie ujęciu Magdalena Urbańska powołuje się na poglądy i aktywność Hannah J. Thompson, mówiące o dowartościowaniu audiodeskrypcji, uznaniu jej za rodzaj twórczości, która mogłaby nawet być nagradzana na filmowych festiwalach (co już się powoli dzieje $)^{16}$. Sama refleksja nad możliwością znalezienia ekwiwalentu między ruchomym obrazem a językowym jego opisem pokazuje w sposób niezwykle uchwytny, w czym może tkwić problem i sztuka poetyckiej ekfrazy filmu. Niewidomy lub niedowidzący słuchacz staje się w tej analogii najlepszym, jeśli można tak powiedzieć, odbiorcą „opowiadania filmu” - jakość narracji będzie się wprost przekładać na jakość powstającego po tej stronie obrazu mentalnego.

\section{Poezja filmowa - w stronę ekfrazy}

Wspomniane w uwagach wstępnych próby porządkowania materiału poezji filmowej budowane mogą być wokół trzech subgenologicznych kryteriów: tematycznego, formalnego i metaforycznego. Nie zawsze można te zbiory w sposób zdecydowany od siebie rozdzielić - i dotyczy to również poszukiwanych tu ekfraz. $Z$ jednej strony mamy w ich przypadku do czynienia z wyraźnym nawiązaniem przedmiotowym: do konkretnego filmu, jego tytułu i poszczególnych elementów. $Z$ drugiej strony natomiast, skoro wstępne rozpoznanie klasyfikuje te wiersze jako ekfrazy właśnie, pojawia się w nich również próba językowego oddania konstytutywnych cech filmu jako dzieła sztuki, które ostatecznie stało się bodźcem do napisania wiersza. $Z$ formalnego punktu widzenia należy zatem w takich przypadkach uwzględnić również kwestie przekładu intersemiotycznego, mimetyzmu formalnego czy w ogóle naśladowania jako pewnej tendencji sztuki, która chce przekroczyć własne tworzywo, ewentualnie je „zmiękczyć"17 (semiotyczna teoria ekfrazy).

W ujęciu wyłącznie „tematycznym”, kiedy dany film staje się pierwszo- bądź drugoplanowym bohaterem wiersza, wyróżnić można kilka wariantów takich transmedialnych odniesień i na różny sposób zebrany materiał scharakteryzować. Punktem dojścia poniższej propozycji jest oczywiście - omówiona osobno - ekfraza, rozumiana już jako „literatura, która zmierza w kierunku filmu"18, ale samą drogę w jej poszukiwaniu warto pokrótce zrekonstruować.

I tak liczną grupę przykładów wierszy, w których pojawiają się tytuły filmów, stanowić będą incydentalne ich przywołania - kontekstowe, pretekstowe lub czysto „fabularne” jako swoiste wydarzenia, będące jedynie tłem czy sygnałem lirycznej sytuacji. Jak pisze Zbigniew Machej w wierszu Mógłbym, nawiązując do seansu filmu Federico Felliniego z 1983 roku:

\footnotetext{
${ }^{16}$ Por. Magdalena Urbańska, „Głos filmu: o audiodeskryptorach”. Ekrany nr 4 (2020): 117; Hannah Thompson, „Audio Description: Turning Access to Film into Cinema Art”. Disability Studies Quarterly 38, nr 3 (2018), https://dsq-sds.org/article/view/6487/5085. (proszę podać datę dostępu)

${ }^{17}$ Por. Erazm Kuźma, „Granice porównywalności poezji z malarstwem i filmem”, w Pogranicza i korespondencje sztuk, red. Teresa Cieślikowska i Janusz Sławiński (Wrocław: Ossolineum, 1980), 267.

${ }^{18} \mathrm{~W}$ ten sposób Jerzy Kossak scharakteryzował wczesną twórczość literacką Piera Paolo Pasoliniego, nawiązując do tytułu jednej z rozpraw samego reżysera i - warto pamiętać - semiotyka filmu: Scenariusz jako „struktura, która chce być innq strukturq"; por. Jerzy Kossak, Kino Pasoliniego (Warszawa: Wydawnictwa Artystyczne i Filmowe, 1976), 16.
} 
Mógłbym opisać, choćby w paru wierszach, co wyprawiałaś będąc ze mną w kinie

kiedy cię znudził film „A statek płynie”19.

W zbliżonym ujęciu umieścić można także wszelkiego rodzaju intertekstualne gry i zabiegi o charakterze ironicznym, w których konkretne filmy to raczej znaki zbiorowej wyobraźni, ale też świadomości filmowej autorów, którzy - właśnie - mogą się nimi posługiwać jak dobrze przyswojonymi tekstami kultury. Dobrym przykładem byłby wiersz Marcina Świetlickiego Casablanca ${ }^{20}$, w którym - właściwie niezależnie od tytułu - mieszają się wątki i postacie „staruszka niepokojąco podobnego do Bogarta” oraz „siedemdziesięcioletniej Marilyn Monroe".

$\mathrm{Na}$ osobną wzmiankę zasługują tutaj teksty poetyckie, które swymi tytułami naprowadzają czytelnika na odpowiednie tropy filmowe, ale już sama lektura utworu nie stanowi prostej kontynuacji skojarzenia. Są to raczej sugestie, które - na zasadzie atrybucji do znanych dzieł sztuki filmowej i z pewnością intencjonalne gesty autorów - pozwalają uruchomić system asocjacji z opowiedzianą w nich historią, jak na przykład w wierszu Złodzieje rowerów Romana Bąka $^{21}$. Tytuł bezsprzecznie otwiera relację z dziełem Vittoria De Siki z 1948 roku, jednakże sama opowieść nie przypomina już tej filmowej. Zauważalne jest jednak podobieństwo kontekstów: bezrobotny ojciec, jego mały synek, głód, bieda tak skrajna, że determinująca egzystencję:

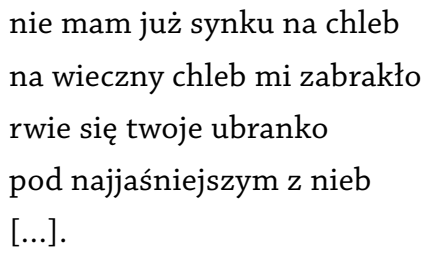

Właściwie podobną charakterystykę zanotować można w odniesieniu do wiersza Krzysztofa Lisowskiego Ballada o Narayamie ${ }^{22}$ - jako, z jednej strony, nawiązaniu do filmu Keisuke Kinoshity z 1958 roku i głównego wątku opowiedzianej w nim historii, z drugiej zaś - jako zuniwersalizowanego już swoistego projektu egzystencjalnego, w którego ramach znajduje się również wędrówka (przenośna lub dosłowna) w kierunku śmierci.

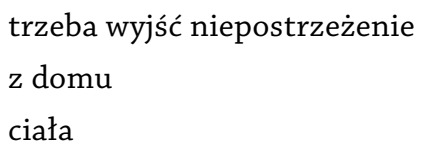

\footnotetext{
${ }^{19}$ Zbigniew Machej, „Mógłbym”, w Dwa zbiory wierszy (Londyn: Puls Publications, 1990), 82.

${ }^{20}$ Marcin Świetlicki, „Casablanca”, w 37 wierszy o wódce i papierosach (Bydgoszcz: Instytut Wydawniczy Świadectwo, 1996), 25.

${ }^{21}$ Roman Bąk, „Złodzieje rowerów”, w Ulica, gdzie sprzedają zapałki (Poznań: Wydawnictwo „W drodze”, 1985), 25.

${ }^{22}$ Krzysztof Lisowski, „Ballada o Narayamie”, w Ciemna dolina (Katowice: Wydawnictwo Śląsk, 1986), 65-66.
} 
ale nie patrzeć za siebie

mijać bezdroża przekraczać strumienie

na Górze spotkać się z Bogiem.

Z kolei całe spektrum przywołań różnego rodzaju daje Grzegorz Olszański w swym tomie Kroniki filmowe ${ }^{23}$. Każdy z trzydziestu sześciu wierszy w zbiorze ma tytuł tożsamy z tytułem mniej lub bardziej znanego filmu (w samym spisie treści podane są nazwiska ich reżyserów, co samo w sobie jest ciekawym zabiegiem) i nie ulega wątpliwości, że poszczególne teksty powstały „pod wpływem” obejrzanego obrazu. I cały tom, i poszczególne, rozmaite relacje, jakie zachodzą pomiędzy sugerowanym w tytule filmem a tekstem, zasługiwałyby właściwie na osobną refleksję, zwłaszcza że w niektórych utworach znaleźć można dodatkowe, mniej oczywiste czy jawne intertekstualne nawiązania, jak na przykład kryptocytaty tytułów innych filmów w wierszu Mondo Cane (film w polskim kontekście dystrybucyjnym funkcjonował także jako Pieski świat): „pieskie popołudnie i człowiek, który pogryzł psa” ${ }^{24}$. (Do innego przykładu $\mathrm{z}$ tomu nawiążę w następnej części artykułu.)

Wyróżniona osobno grupa „recenzji”, charakteryzująca się wyraźnym tonem oceniającym, nie reprezentuje, cechujących się opisowością, ekfraz „właściwych. Ma też ona charakter zgoła inny niż wspomniane w uwagach wstępnych międzywojenne poetyckie recenzje $\mathrm{z}$ filmów, pełne zachwytu i uniesienia, pisane z perspektywy zaangażowanego emocjonalnie widza, impresyjne i zwykle skupione na atrakcjach związanych z samym fenomenem kina jako sztuką ruchomych obrazów, nowinek technicznych i niedosiężonych gwiazd, które się kocha bezgraniczną miłością. Przykłady współczesne są raczej krytyczne, dekonstrukcyjne, nierzadko ironiczne. Tak można odczytać postawę obserwatora z kolażowego poematu Non-stop-show Tadeusza Różewicza, w którym pojawia się fragment dotyczący Lolity Stanleya Kubricka z 1962 roku (na zasadzie łączenia fragmentów tekstów, cytatów, napisów pojawia się w innym miejscu utworu nawet wyimek z rzeczywistej [?] gazetowej recenzji filmu):

\footnotetext{
[...] Lolitę widziałem w Monachium

Lolita Ta lolita to bardzo nudny długi

film z doskonałym aktorem który jest zły

w tym filmie lolita to taki sopelek

lodu dziewczynka bez zarostu pod pachami

jak laleczka On decent czy coś w tym rodzaju

Lolita okrutna naga laleczka bez włosów

tu i tam ta drewniana piła ten nudny

melodramat idzie od miesięcy w największym

kinie Monachium Royal-Theater

$[\ldots]^{25}$.
}

\footnotetext{
${ }^{23}$ Grzegorz Olszański, Kroniki filmowe (Warszawa: Lampa i Iskra Boża, 2006).

${ }^{24}$ Grzegorz Olszański, Mondo Cane, w Olszański, Kroniki filmowe, 43. Przytoczona fraza to kontaminacja tytułów obrazów Sidneya Lumeta (Pieskie popołudnie, 1975) oraz Człowiek, który pogryzł psa (1992), autorstwa trzech reżyserów: André Bonzela, Benoît Poelvoorde oraz Rémy'ego Belvaux (polski tytuł „pożyczony” jest zresztą z propozycji angielskiej, a nie oryginalnej: C'est arrivé près de chez vous).

${ }^{25}$ Tadeusz Różewicz, „Non-stop-show”, w Utwory zebrane. Poezja, t. 2 (Wrocław: Wydawnictwo Dolnośląskie, 2006), 407-408; z tomu Twarz trzecia (1968).
} 
Podobnie ironicznie (przynajmniej na początku), ale przede wszystkim z wyraźnym dystansem (i czasowym, i emocjonalnym) względem klasycznej opowieści filmowej, patrzy Marta Podgórnik w wierszu Streszczając niezaznajomionym „Przeminęło z wiatrem"26. Sama formuła tytułowa kieruje odbiorcę w stronę „opowiadania filmu”, zaś ostatecznie ironia - w trakcie opowiadania o losach Scarlett O’Hary - zamieni się w empatię, a narracja o filmowych wydarzeniach niepostrzeżenie przeniknie do świata i „streszczającej”, i czytających:

Ashley, pomimo najszczerszych intencji, nie mógł ożenić się z panną O’Hara.

Ashley ożenił się z panną Hamilton, ze względu na pokrewne zainteresowania.

Scarlett ze złości wyszła za Karola, który - na szczęście, zginął na wojnie.

Scarlett nie mogła przewidzieć, jak bardzo zmieni jej życie kolejny związek -

$[\ldots]$

Najpierw utraci dziecko, potem straci miłość.

Pomyślę o tym jutro, tak sobie powtarza.

Najpierw pęka ci serce, potem ta kra cienka.

Pomyślę, myśli, o innych witrażach.

Jeszcze inną relację intertekstualną i intersemiotyczną zaliczyłbym do poetyckich trawestacji bądź aktualizacji filmów. Wiersz Jerzego Harasymowicza o incipicie „W środek miasta" 27 nie sugeruje niczego w tytule, a rzecz rozpoczyna się uniwersalną opowieścią o kobiecie i mężczyźnie (z jego punktu widzenia), o ich wspólnym losie. Dopiero w trakcie narracji pojawia się fragment „Wierzyła że robię cuda / mityczny Zampano / łamie podkowy / (z dykty) / w chmurach", stanowiący już bezpośrednie nawiązanie do La Strady Federica Felliniego z roku 1954, której - w jakimś stopniu - współczesnym i zakorzenionym w innym kontekście wariantem jest smutna historia z wiersza („Popychała wózek / krakowskiej biedy").

W ten sposób słynna opowieść filmowa potraktowana została jako swoista matryca - w tym przypadku - historii miłosnej i przyłożona do opowieści „własnej”. Podobny zabieg stosuje Maciej Woźniak w wierszu Bonnie i Clyde ${ }^{28}$. Tym razem dzięki tytułowej wskazówce czytelnik nie ma wątpliwości, że dialog kochanków odnosi się do konkretnego filmu (reż. Arthur Penn, 1967), wydarzeń w nim opowiedzianych, a nawet do poszczególnych ujęć i sposobu ich wykonania (scena obławy i zabicia głównych bohaterów właśnie ze względu na mistrzowskie operowanie kamerami i montażem przeszła do historii kina oraz pamięci widzów):

\footnotetext{
${ }^{26}$ Marta Podgórnik, „Streszczając niezaznajomionym Przeminęło z wiatrem”, w Zawrót głowy. Antologia polskich wierszy filmowych, red. Darek Foks (Łódź: Narodowe Centrum Kultury Filmowej, 2018), 278 (z tomu Dwa do jeden, 2006).

${ }^{27}$ Jerzy Harasymowicz, „W środek miasta”, w Od Staffa do Wojaczka. Poezja polska 1939-1985. Antologia, red. Bohdan Drozdowski i Bohdan Urbankowski (Łódź: Wydawnictwo Łódzkie, 1988), t. 2, 244-245 (z tomu Klękajcie narody, 1984).

${ }^{28}$ Maciej Woźniak, „Bonnie i Clyde”, w Zawrót głowy. Antologia polskich wierszy filmowych, 280-281 (gdzie podana jest informacja o źródle wiersza [tom Iluzjon, 2008], podczas gdy pochodzi on z tomu Wszystko jest cudze [2005]).
} 


\author{
$[\ldots]$ \\ Chciałam (byliśmy młodzi i myśleliśmy: to nic, kiedy boli) \\ żeby kręcili z czterech kamer, jak do nas strzelają, \\ po dobrym montażu będzie wyglądało, jakbyśmy tańczyli. \\ Chciałem, żebyśmy leżeli cali we krwi, \\ i żeby to inni, nie my, musieli czytać końcowe napisy.
}

W próbie wykorzystania filmowej matrycy do opisania „swojej” historii zabiegi Woźniaka są tak sugestywne, że właściwie - gdyby nie owo zapośredniczenie („chciałam” / „chciałem”) utwór ten sytuowałby się już bardzo blisko ekfrazy.

\title{
Ekfraza i jej „widz”
}

W literaturoznawczej refleksji na temat ekfrazy pojawia się wspólny punkt odniesienia: retoryczna tradycja (literackiego) opisu, a nawet „dokładnego opisu” dzieła sztuki, najczęściej obrazu, rzeźby czy architektury. W ramach konstytutywnych wyznaczników tak scharakteryzowanego poetyckiego gatunku Adam Dziadek wymienia oznaki metajęzykowe (tytuł dzieła sztuki, nazwisko malarza itd.) oraz „elementy opisu dzieła sztuki umieszczone wewnątrz tekstu literackiego”29 (konteksty opisywanego dzieła, jego cechy gatunkowe, charakterystyczne motywy twórczości artysty itd.). Na potrzeby niniejszych rozważań dodatkowo wyodrębniłbym z owej refleksji i zaakcentował trzy istotne kwestie. Po pierwsze, współczesne badania nad ekfrazą skupione są przede wszystkim na samym języku opisu: jego możliwościach, jego retorycznych ograniczeniach, wreszcie jego perswazyjnej mocy ${ }^{30}$. Jak w skondensowany sposób definiuje ekfrazę James A.W. Heffernan, jest to „werbalne odzwierciedlenie wyobrażenia wizualnego" ${ }^{31}$. Po drugie, nie do końca chodzi w ekfrazie o wierność czy jakkolwiek inaczej pojmowaną „odpowiedniość” - ekfraza nie jest reprodukcją, lecz interpretacją. W tym sensie kluczowa w jej definiowaniu okazuje się perspektywa opowiadającego: „Ekfraza opisuje dzieło sztuki, ale nie tylko, opisuje bowiem także tego, kto to dzieło ogląda”32. Po trzecie wreszcie, „problemem” ekfrazy jest również sam akt odbioru: zespół procesów natury intelektualnej, sensualnej i - zwłaszcza - dotykających sfery wyobraźni czytelnika czy słuchacza poetyckiego „opowiadania filmów”. Na kluczowe pytanie zaś, czy istnieje i jak istnieje poetycka ekphrasis dzieła filmowego, przyjdzie odpowiedzieć po krótkiej analizie kilku przykładów.

Krystyna Rodowska pod tytułem swego wiersza Ruchome piask ${ }^{33}$ umieściła rozstrzygającą informację: „(z inspiracji filmem Kobieta z wydm)”. To nie tylko swoista podpowiedź, bez której

\footnotetext{
${ }^{29}$ Por. Adam Dziadek, Obrazy i wiersze. Z zagadnień interferencji sztuk w polskiej poezji wspótczesnej (Katowice: Wydawnictwo Uniwersytetu Śląskiego, 2004), 55.

${ }^{30}$ Por. Dziadek, 53; Michał Paweł Markowski, „Ekphrasis. Uwagi bibliograficzne z dołączeniem krótkiego komentarza", Pamiętnik Literacki XC, z. 2 (1999).

${ }^{31}$ Cyt. za: Danuta Mirka, „Czy istnieje muzyczna Ekphrasis?”, Ruch Muzyczny nr 18 (2001): 35.

${ }^{32}$ Dziadek, Obrazy i wiersze. Z zagadnień interferencji sztuk w polskiej poezji współczesnej, 72.

${ }^{33}$ Krystyna Rodowska, „Ruchome piaski”, w Nic prócz O. Wiersze z lat 1968-2018 (Warszawa: PIW, 2019), 19 (z tomu Gesty na śniegu, 1968).
} 
czytelnik nie rozpoznałby źródła owej inspiracji, a nawet nie dowiedziałby się, że u źródeł powstania tekstu jakakolwiek inspiracja zaistniała. Przede wszystkim uwagę tę traktować należy jako quasi-gatunkową kwalifikację, mówiącą o drodze twórczej (do filmu do wiersza), o konkretnej relacji transmedialnej (filmowa Kobieta z wydm vs. wiersz), wreszcie o uczciwości przyjętej perspektywy: nawiasowy podtytuł zdecydowanie precyzuje i zawęża charakter „filmowej opowieści”. Oczywiście, jak już zostało to odnotowane, nawet w przypadku restrykcyjnego nastawienia na definiowanie poetyckiej ekfrazy dzieła filmowego nie może być mowy o poszukiwaniu jakiejś fabularnej przyległości czy adekwatności. W większości przypadków - zgodnie ze sztuką ekfrazy - poeta dokonuje wyboru, patrzy i pisze przez określony pryzmat, najczęściej odwołując się do pamięci oraz wrażeń i powidoków w niej zapisanych. Wydaje się, że w wierszu Rodowskiej - zamiast „opowiadania filmu” - pojawia się zapis kondensacji znaczeń (historia przedstawiona w Kobiecie z wydm jako parabola egzystencji, procesu poznawania samego siebie i swych możliwości życia w relacji z Innym oraz w społeczeństwie) oraz charakterystycznych wyznaczników formalnych (na przykład skupienie na fakturach: piasku, wody, ludzkiego ciała):

\author{
Zasypani powracają do tego co najbliższe \\ Ich słuch jest wynikiem przesypywania się piasku \\ w przeźroczystych klepsydrach ciał \\ Miarka piasku, miarka losu \\ Ich źrenice są otwarte i czarne \\ jak obojętność wody pozostałej na dnie \\ W języku silnych tutaj: pij zabij! \\ Po sznurowanej drabince wyobraźni \\ wspina się z dołu tylko śmiech
}

W ich słonej skórze są powiększone ziarna

wszystkich tajemnic

ławice snu przejęte koralowym dreszczem

wilgotne pnie dotyku z bolesnym nacięciem

Nad głową ptak się waży jeszcze nienazwany

Zasypani powracają do tego co najdalsze

bo nie wiedzą że piekłem jest właśnie ucieczka.

Inną perspektywę przyjął Andrzej Kuśniewicz w wierszu Filmowa Skandynawia (Harriet Anderson) ${ }^{34}$. Zarówno podane w należącym do tytułu nawiasie imię i nazwisko aktorki, jak i konglomerat motywów, skojarzeń czy fabularnych szczegółów (trupa cyrkowców, podróż, kolejne obozowiska, Skagen, zaraza) prowadzą do przekonania, że świat opisany w wierszu to również - prawdopodobnie - konglomerat filmów. Z jednej strony będzie to na pewno Wieczór kuglarzy, dzieło Ingmara Bergmana z 1953 roku (właśnie z udziałem Anderson), z drugiej - być może odwołania do innych przykładów „filmowej Skandynawii”, niekoniecznie w jej wersji bergmanowskiej:

\footnotetext{
${ }^{34}$ Andrzej Kuśniewicz, „Filmowa Skandynawia (Harriet Anderson)”, w Czas prywatny (Warszawa: PIW, 1962), 11-12.
} 
Heroldy u bram

Zaraza w Skagen

Skagen zamknięte

Od nocy podkowiało

Łazarz

z deską na oczach

białokonnym morzem

w mróz

Aż do ostatnich godzin płynął

nad wędrowcami namiot w chmurze

Zachodziło w pożar gdy mówiła:

$$
\begin{aligned}
& \text { - jestem silniejsza od ciebie } \\
& \text { zginam podkowy } \\
& \text { ujeżdżam znarowione konie } \\
& \text { moje uda - gdy nimi - } \\
& \text { to najmocniejszy ogier } \\
& \text { - popróbuj! }
\end{aligned}
$$

\footnotetext{
W żółtych płachtach

godziny zasłonięte

Skagen nocą milczące

Skagen na łańcuch zamknięte.
}

Z kolei Bohdan Zadura w wierszu Siódma pieczęćc już samym tytułem odsyła czytelnika do bardzo charakterystycznego, niepodrabialnego imaginarium filmu Bergmana z 1957 roku: to konkretne postaci („, snach widzą drwala rycerza i diabła”), rekwizyty i motywy, ale także próba przywołania surowej, mrocznej, niepokojącej atmosfery świata przedstawionego dzieła, wraz z kluczowym przekonaniem na temat śmierci jako tego, co nieuniknione:

$$
\begin{aligned}
& \text { kiedy ćmy wielkie siadają na wzgórzach } \\
& \text { siedem lichtarzy niby słońce świeci } \\
& \text { do snu się kładą zwierzęta i dzieci } \\
& \text { po nieskończonych znużone podróżach } \\
& \text { w snach widzą drwala rycerza i diabła } \\
& \text { i widzą tabun uskrzydlonych koni }
\end{aligned}
$$


i w śnie dopada ich tętent pogoni -

ostatnia gwiazda do otchłani spadła

drzewo się zwali dosięgnie nas kamień

echo nas zwiedzie które schwycić trudno

po drodze może napotkamy zamek

i jak zwierzęta ruszamy na północ

zamek odpływa i odpływa góra

i śmierć jak jastrząb dopada nas w chmurach.

Kazimierz Hoffman daje sygnał innego rodzaju, tytułując swój utwór nazwiskiem reżysera: Kurosawa ${ }^{36}$. Pozostaje pytanie o czytelnicze rozpoznanie. Być może wystarczy postać Makbeta, by odnaleźć skojarzenie z Tronem we krwi japońskiego twórcy (1957), ale równie sugestywna okazuje się ekwiwalencja zapamiętanego z filmu obrazu:

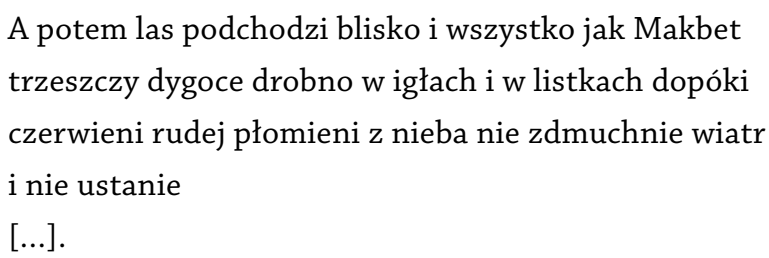

Wspomniany już wcześniej tom poetycki Grzegorza Olszańskiego Kroniki filmowe daje wiele możliwości interpretacyjnych i z pewnością udaje się w nim odnaleźć także przykłady ekfraz „właściwych” (pozostawiając na marginesie wszelkie pozostałe „ekfrastyczne” próby, a więc w zasadzie cały tom). Szczególnie ciekawy jest tekst, w którym problem werbalizacji tego, co wizualne, podlega tematyzowaniu, jak w wierszu Ziemia i popioły (tytuł filmu w reżyserii Atiqa Rahimiego z 2004 roku). W ten oto sposób dodatkowo „unaocznione” zostały kulturowa praktyka i teoretyczny problem „opowiadania filmu”:

1.

Szeroki plan, krótkie cięcia, nagłe zbliżenia.

Historia opowiadana obrazami, fabuła poszarpana dźwiękiem,

słowo po słowie, klatka po klatce.

2.

Stary mężczyzna i chłopiec idą wolno przez kinowy ekran.

Za nimi spalona wioska i pamięć naszpikowana minami zapomnienia.

Co daje się uwieść przez nic. Nic daje się oswoić

temu czemuś, czego nie sposób nazwać.

\footnotetext{
${ }^{36}$ Kazimierz Hoffman, „Kurosawa”, w Trwajaca chwila (Bydgoszcz: Ośrodek Kultury Regionalnej, 1991), 31.
} 
3.

Na trzecim planie słowa, którym kończy się termin ważności (bezsens, sens, sen). Papierowy język połyka

kolejne litery. W alfabecie brakuje już

s.o.s.

Trafnie „metodę” Olszańskiego komentuje Karol Maliszewski, formułując przy okazji jedną z możliwych definicji poetyckiej ekfrazy filmu: „Tu naprawdę nie opowiada się treści przeżytych filmów. Raczej szuka się ekwiwalentów. Szuka się krótkiej, błyskotliwej, wieloznacznej konstrukcji słownej, która byłaby odpowiednikiem doświadczenia filmowego, kumulując w sobie obrazowość i emocjonalność, wygaszane na koniec intelektualną ripostą o aforystycznym wydźwięku"37.

W ramach podsumowania tego wątku należy podkreślić, że poetycka ekfraza dzieła filmowego jest możliwa, nawet jeśli założymy, że restrykcyjne reguły retoryki nie pozwalają mówić o jej pełnych realizacjach. Jak pisał w kontekście ekfraz plastycznych Adam Dziadek: „Najczęściej dzieje się tak, że owe utwory spełniają wyznaczniki ekfrazy jedynie po części i lepiej byłoby mówić o ich ekfrastyczności czy ich charakterze ekfrastycznym" ${ }^{38}$. Także w odniesieniu do ekfraz filmowych problemem nie do pokonania pozostaje przede wszystkim „natura” języka, który z trudem i nie zawsze jest w stanie całkowicie oddać to, co niejęzykowe, a co stricte „filmowe”: audiowizualne, przemijające, niemożliwe do „zacytowania”. Odmienne statusy ontologiczne dialogujących ze sobą dzieł - tekstu poetyckiego i filmu - uniemożliwiają "odpowiedniość", stąd omawiane ekfrazy skupione są najczęściej na elementach wybranych i szczególnych: fragmencie filmu, pojedynczym obrazie (kadrze), jakiejś scenie, a także na uchwyconej dominancie: atmosferze, nastroju, kolorystyce. Nie ulega także wątpliwości, że każdy z tych wierszy, oprócz tego, że jest o filmie, jest także o czymś innym - co należałoby wydobyć w procesie interpretacji, jednakże jedna kwestia - zasugerowana już w cytacie z Maliszewskiego - domaga się niezależnego uzupełnienia.

Zdecydowana większość zacytowanych wyżej ekfraz (lub filmowych wierszy o charakterze ekfrastycznym) to utwory powstałe $z$ inspiracji konkretnym dziełem filmowym, a zatem, jak się okazuje, istotna jest w nich również warstwa przeżycia kinematograficznego: właśnie ten obraz okazał się na tyle silny, by owo przeżycie odnotować w wierszu. Wysiłek poetyckiego opisu skierowany jest więc nie tylko w stronę dzieła, lecz także jego odbioru, doświadczenia, samego seansu. W Horacjańskiej formule „poemat to jak obraz” (ut pictura poesis) nie ma wprost mowy o procesie przekładu (dzieła na dzieło), ale o porównaniu sytuacji odbiorczej właśnie, która - w pewnym zakresie - może przynieść podobny efekt. To właśnie w owym „jak” szukam zbieżności postaw odbiorczych, przeżyć, doświadczeń estetycznych, wrażeń, jakie film wywołuje, a te, najczęściej, możliwe są do porównania ze względu na ich niejęzykowy charakter. W przywoływanym już wierszu Kurosawa Kazimierza Hoffmana, po opisie

\footnotetext{
${ }^{37}$ Karol Maliszewski, „Poeta już nie musi na Judahu skale”, w Po debiucie. Dziennik krytyka (Wrocław: Biuro Literackie, 2008), 121.

${ }^{38}$ Dziadek, Obrazy i wiersze. Z zagadnień interferencji sztuk w polskiej poezji wspótczesnej, 55; wyróżnienie - R.K.
} 
nadchodzącego wojska w leśnym kamuflażu, czyli ostatniego ujęcia filmu - uruchomiona zostaje perspektywa widza, pozostawionego z silnie oddziałującą na wyobraźnię sceną i nagłym zakończeniem seansu:

Ale napięcie trwać będzie jeszcze przez długi czas serce wciąż spieszy i ptaki kreślą czarne inicjały jednym błyskiem.

Szczególnie ciekawym przykładem w tak zarysowanej charakterystyce ekfrazy są dwa wiersze Stanisława Grochowiaka: „Joanna D’Arc” Dreyera ${ }^{39}$ oraz Męczeństwo Joanny wg Dreyera ${ }^{40}$ - właściwie oba tematyzujące sam akt recepcji niemego arcydzieła z 1928 roku. W pierwszym z nich porównane zostały dwa „style odbioru”: naukowy („Nie ożywi mnie okrzyk z ostatnich zupełnie krzeseł / «Przypatrzcie się teraz panowie brodawce na wardze biskupa!»") oraz zindywidualizowany, w którego ramach siła przeżycia zwycięża z pokusą zimnej wiwisekcji („Drgam przebity strzałą / Pospolitej szpetoty i męki Falconetti”). Drugi, nieco późniejszy wiersz, również w większym stopniu niż dzieła dotyczy intensywności kinematograficznego seansu (ciemność „Siada na sercu i drapie łapami”) i - po zakończeniu projekcji - jego konfrontacji ze świadomością iluzji, w jakiej się uczestniczyło:

Więc ciemność dymu to tylko kurtyna

Patrz mocny Boże mamy oto litość

Trzaskają klapy po napisie FIN

Salwa tysiąca zabitych obiadów.

Wreszcie ostatni przykład w zaproponowanym zestawieniu - krótki tekst Jerzego Oszeldy pod tytułem Fanny i Aleksander, bez wątpienia naprowadzający na film Bergmana z 1982 roku, ale w całości poświęcony próbie aforystycznego oddania stanu widza po zakończonej projekcji:

Świadomość moja otrzymała uderzenie strumienia

drugiej świadomości

Natężenie egzystencjalne 1 Bergman (Bg).

\section{Konkluzje}

Zaproponowane tu rozważania prowadzą do sformułowania dwóch - zasugerowanych w tytule artykułu - konkluzji. Z jednej strony, na pytanie, czy możliwa jest poetycka ekfraza dzieła filmowego, odpowiadam twierdząco, wspierając się dodatkowo argumentami na temat „ekfrastyczności”, sformułowanymi w innym kontekście przez Adama Dziadka, i przywołując wiele przykładów ekfraz możliwie pełnych. Od razu jednak trzeba zaznaczyć, że

\footnotetext{
${ }^{39}$ Stanisław Grochowiak, „Joanna D’Arc Dreyera”, w Wiersze nieznane i rozproszone (Wrocław: Towarzystwo Przyjaciół Polonistyki Wrocławskiej, 1996), 87 (wiersz datowany na lata 1954-1956).

${ }^{40}$ Stanisław Grochowiak, „Męczeństwo Joanny wg Dreyera”, w Wiersze nieznane i rozproszone, 138 (wiersz datowany na lata 1957-1963).
} 
taką oddalającą od klasycznej czy tradycyjnej ekfrazy cechą są dość częste (to osobna pula przykładów) przypadki przekierowania perspektyw: od samego dzieła w stronę relacji na temat oglądania filmu. O ile ekfraza dzieła plastycznego jest możliwa przez dokładny opis (zbliżenie do hypotypozy), o ile ekfraza dzieła muzycznego jest możliwa dzięki zastosowaniu odpowiednich zabiegów językowych (muzyczność literatury) i/lub strukturalnych (na przykład w odniesieniu do kompozycji), o tyle w przypadku ekfraz odnoszących się do poszczególnych filmów stosunkowo często pojawia się kwestia opisu samego aktu odbioru ${ }^{41}$ : kinematograficznego przeżycia, niejednokrotnie będącego wydarzeniem formującym, a w każdym razie na tyle silnego, by poddać je próbie poetyckiej refleksji. W takim ujęciu zaś na szczególnych prawach funkcjonuje również czytelnik wiersza, będący zarazem widzem filmowym (pamiętającym wyjściowe, opisywane w wierszu dzieło - i konfrontującym dwie perspektywy: poetycką oraz własną).

Z powyższymi uwagami związana jest konkluzja druga. Tak jak istniała i chyba ciągle istnieje potrzeba czy konieczność opowiadania filmów, tak zrozumiała jest również poetycka reakcja na film. To przecież także - mająca określone przyczyny i cele - forma „opowiadania filmu”. I znów: niekoniecznie efekt będzie ekfrazą „właściwą”, niekoniecznie - z teoretycznego i genologicznego punktu widzenia - należy te próby obejmować pojęciem ekfrazy. Być może bardziej adekwatne byłoby tu przejście w refleksji z pola retoryki na grunt antropologii kina, zainteresowanej wszelkimi praktykami okołofilmowymi, w tym opowiadaniem filmów, w tym pisaniem i czytaniem wierszy o filmach. Na marginesie można dodać, że problemowy i/lub chronologiczny układ wierszy, nawiązujących do konkretnych obrazów, pozwala je czytać również jako historię recepcji - co i kiedy oglądano, co wywarło tak wielki wpływ na poetów, co „zasługiwało” na wiersz.

W ujęciu antropologii kina opowiadanie filmów to po prostu codzienna czynność (coś, co ludzie „robią” z filmami), przybierająca rozmaite - uwarunkowane czasem bardzo odmiennymi kontekstami kulturowymi - formy i manifestacje. Właściwie do truizmów należy twierdzenie, że film odmienił kształt dwudziestowiecznej (oraz późniejszej) kultury i sztuki, w tym poezji. Wydaje się jednak, że szczególnie interesującą rolę do odegrania miała i ma w tej historii praktyka „opowiadania filmów” / „opowiadania o filmach”, codzienna i kunsztowna zarazem, definiowana jako egzystencjalna potrzeba - co znajduje odzwierciedlenie również w poezji.

${ }^{41}$ Dziadek, Obrazy i wiersze. Z zagadnień interferencji sztuk w polskiej poezji wspótczesnej, 71-72. 


\section{Bibliografia}

Bąk, Roman. „Złodzieje rowerów”. W Ulica, gdzie sprzedaja zapałki, 25. Poznań: Wydawnictwo „W drodze”, 1985.

Berowska, Marta. „Do S. Wyspiańskiego”. Poezja nr 7-8 (1985): 93.

Dym, Jeffrey. „A Brief History of Benshi (Silent Film Narrators)". https://aboutjapan. japansociety.org/content.cfm/a brief history of benshi. (dostęp: 15.05.2021)

Dziadek, Adam. Obrazy i wiersze. Z zagadnień interferencji sztuk w polskiej poezji wspótczesnej. Katowice: Wydawnictwo Uniwersytetu Śląskiego, 2004.

Głownia, Dawid. Początki kina w Japonii na tle przemian społeczno-politycznych kraju. Wrocław: Atut, 2020.

Grochowiak, Stanisław. „Joanna D’Arc Dreyera”. W Wiersze nieznane i rozproszone, 87. Wrocław: Towarzystwo Przyjaciół Polonistyki Wrocławskiej, 1996.

-——. „Męczeństwo Joanny wg Dreyera”.

W Wiersze nieznane i rozproszone, 138.

Wrocław: Towarzystwo Przyjaciół Polonistyki Wrocławskiej, 1996.

Harasymowicz, Jerzy. „W środek miasta”. W Od Staffa do Wojaczka. Poezja polska 1939-1985. Antologia. T. 2. Zredagowane przez Bohdan Drozdowski i Bohdan Urbankowski, 244-245. Łódź: Wydawnictwo Łódzkie, 1988.

Hoffman, Kazimierz. „Kurosawa”. W Trwajaca chwila, Bydgoszcz: Ośrodek Kultury Regionalnej, 1991.

Jerzakowska, Beata. „Ekfraza poetycka w audiodeskrypcji". Polonistyka nr 5 (2013): 10-13.

Kossak, Jerzy. Kino Pasoliniego. Warszawa: Wydawnictwa Artystyczne i Filmowe, 1976.

Kucharczyk, Janusz. „Pierwiastki filmowe w twórczości literackiej Tadeusza Peipera i Jalu Kurka". Kwartalnik Filmowy nr 1 (1965): 44-52.

Kuśniewicz, Andrzej. „Filmowa Skandynawia (Harriet Anderson)". W Czas prywatny, 11-12. Warszawa: PIW, 1962.
Kuźma, Erazm. „Granice porównywalności poezji z malarstwem i filmem”. W Pogranicza $i$ korespondencje sztuk. Zredagowane przez Teresa Cieślikowska i Janusz Sławiński, 257269. Wrocław: Ossolineum, 1980.

Letelier, Hernán Rivera. Opowiadaczka filmów. Przetłumaczone przez Natalia Nagler. Warszawa: Muza, 2012.

Lisowski, Krzysztof. „Ballada o Narayamie”. W Ciemna dolina, 65-66. Katowice: Wydawnictwo Śląsk, 1986.

Loska, Krzysztof. „Benshi jako współautor filmu”. Kwartalnik Filmowy nr 59 (2007): 59-65.

Machej, Zbigniew. „Mógłbym”. W Dwa zbiory wierszy. Londyn: Puls Publications, 1990.

Madej, Alina. „Między filmem a literaturą. Szkic o powieści filmowej”. W Film polski wobec innych sztuk. Zredagowane przez Alicja Helman i Alina Madej, 102-123. Katowice: Uniwersytet Śląski, 1979.

Maliszewski, Karol. „Poeta już nie musi na Judahu skale”. W Po debiucie. Dziennik krytyka, 120-122. Wrocław: Biuro Literackie, 2008.

Markowski, Michał Paweł. „Ekphrasis. Uwagi bibliograficzne z dołączeniem krótkiego komentarza". Pamiętnik Literacki XC, z. 2 (1999): 229-236.

Mirka, Danuta. „Czy istnieje muzyczna Ekphrasis?”. Ruch Muzyczny nr 18 (2001): 35-37.

Olszański, Grzegorz. Kroniki filmowe. Warszawa: Lampa i Iskra Boża, 2006.

Otto, Wojciech. Literatura i film w kulturze polskiej dwudziestolecia międzywojennego. Poznań: Wydawnictwo PTPN, 2007.

Podgórnik, Marta. „Streszczając niezaznajomionym "Przeminęło z wiatrem»". W Zawrót głowy. Antologia polskich wierszy filmowych. Zredagowane przez Darek Foks. Łódź: Narodowe Centrum Kultury Filmowej, 2018 . 
Pytaszowie, Ewa i Marek. „Poetycka podróż w świat kinematografu, czyli kino w poezji polskiej lat 1914-1925". W Szkice z teorii filmu. Zredagowane przez Alicja Helman i Tadeusz Miczka, 18-32. Katowice: Uniwersytet Śląski, 1978.

Rabon, Izrael. Ulica. Przetłumaczone przez Krzysztof Modelski. Wrocław: Wydawnictwo Dolnośląskie, 1991.

Rodowska, Krystyna. „Ruchome piaski”. W Nic prócz O. Wiersze z lat 1968-2018. Warszawa: PIW, 2019.

Różewicz, Tadeusz. „Non-stop-show”. W Utwory zebrane. Poezja, t. 2, 404-413. Wrocław: Wydawnictwo Dolnośląskie, 2006.

Siutsova, Alena. „Kino opowiadane. Historia i teoria”. Praca magisterska, Uniwersytet Warszawski, 2014.

Szymczyk-Kluszczyńska, Grażyna. „Opowiadam? Opisuję? (Poeci-surrealiści wobec kina)". W Małe formy narracyjne. Zredagowanie przez Eugenia Łoch, 106-113. Lublin: Wydawnictwo UMCS, 1991.

Szymczyk-Kluszczyńska, Grażyna i Ryszard W. Kluszczyński. „Poemat kinematograficzny. Analiza pewnego typu związków między literaturą a kinem". Przegląd Humanistyczny nr 11 (1982): 35-53.
Świetlicki, Marcin. „Casablanca”. W 37 wierszy o wódce i papierosach, 25. Bydgoszcz: Instytut Wydawniczy Świadectwo, 1996.

Thompson, Hannah. „Audio Description: Turning Access to Film into Cinema Art". Disability Studies Quarterly 38, nr 3 (2018). https://dsq-sds.org/article/view/6487/5085. (dostęp: 15.05.2021)

Urbańska, Magdalena. „Głos filmu: o audiodeskryptorach”. Ekrany nr 4 (2020): 116-120.

Więckowski, Robert. „Audiodeskrypcja piękna”. Przekładaniec nr 28 (2014): 109-123.

Woźniak, Maciej. „Bonnie i Clyde”. W Zawrót głowy. Antologia polskich wierszy filmowych. Zredagowane przez Darek Foks, 280-281. Łódź: Narodowe Centrum Kultury Filmowej, 2018

Zadura, Bohdan. „Siódma pieczęć”. W W krajobrazie z amfor. Warszawa: Czytelnik, 1968. 


\section{SŁOWA KLUCZOWE:}

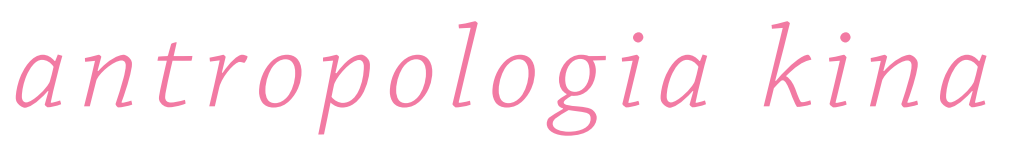

\section{E K F R A Z A}

\section{poezja filmowa}

\section{ABSTRAKT:}

W artykule podjęta została próba zgromadzenia oraz interpretacji kilkunastu wierszy filmowych, m.in. S. Grochowiaka, K. Rodowskiej, A. Kuśniewicza, B. Zadury, K. Hoffmana, J. Oszeldy, G. Olszańskiego. Spośród rozmaitych przykładów relacji transmedialnych (film - literatura) wyróżniono te przykłady, które można by - zgodnie z tradycją retoryczną - nazwać ekfrazami. Fenomen poetyckich ekfraz dzieł filmowych uzupełniony został o kontekst kulturowy związany z odmiennymi tradycjami opowiadania filmów, traktowanych jako powszechna praktyka (amatorska, profesjonalna, artystyczna) i ujmowanych w ramach antropologii kina. 


\section{przekład intersemiotyczny}

\section{O P O W I A D A N I E F I L M U}

\section{NOTA O AUTORZE:}

Rafał Koschany (1975) - prof. UAM dr hab., kierownik Zakładu Semiotyki Kultury w Instytucie Kulturoznawstwa Uniwersytetu im. Adama Mickiewicza w Poznaniu, redaktor naczelny kwartalnika „Kultura Współczesna. Teorie - Interpretacje - Praktyka”. Swoje zainteresowania badawcze skupia na teorii interpretacji, pograniczu literaturoznawstwa i filmoznawstwa, kulturowych studiach miejskich oraz edukacji kulturowej. Autor książek Przypadek. Kategoria artystyczna i literacka $w$ literaturze i filmie (2006, II wyd. 2016) i Zamiast interpretacji. Między doświadczeniem kinematograficznym a rozumieniem filmu (2017), a także licznych artykułów publikowanych $\mathrm{w}$ czasopismach naukowych oraz tomach zbiorowych. Współredaktor kilku książek, m.in.: Horyzonty interpretacji. Wokót myśli Paula Ricoeura (2003), Fenomen słowa (2009), Musical. Poszerzanie pola gatunku (2013), Republika musicali. Historia - gatunek - interpretacje) (2020), Kultury w ruchu. Migracje, transfery, epistemologie (2019). 